\title{
Networks in the context of digital culture: technologies, coordinators, university teachers and students
}

\author{
Redes no contexto da cultura digital: tecnologias, coordenadores, professores e \\ alunos universitários
}

\section{Redes en el contexto de la cultura digital: tecnologías, coordinadores, profesores y estudiantes universitarios}

\author{
Maria Cristina Lima Paniago ${ }^{1}$ \\ Rosimeire Martins Régis dos Santos ${ }^{1}$ \\ Arlinda Cantero Dorsa ${ }^{1}$
}

\begin{abstract}
This research aims to analyze networks of relations in the context of digital culture, focusing on the relationships among technologies, coordinators, university teachers, and students. It is qualitative research with virtual etnography approach, developed in a private university in the Center-West of Brazil, with the participation of 39 university teachers, 285 students and 7 coordinators, answering questionnaires and semistructured interviews, and posting messages at Facebook, related to the digital culture and to the formative educational process. The results point to a context of mismatch between the comings and goings of university teachers, students and coordinators, seeking to appropriate the technologies in order to invent other ways of teaching and learning, in different times and spaces, individually and collaboratively, with openness to the innovation in a critical way.
\end{abstract}

Keywords: digital culture; technologies; formative educational process; virtual etnography approach.

Resumo: Resumo: Esta pesquisa tem o objetivo de analisar redes de relações no contexto da cultura digital, com enfoque nas ligações entre tecnologias, coordenadores, professores universitários e alunos. Trata-se de uma pesquisa qualitativa, com abordagem de etnografia virtual, desenvolvida em uma universidade privada do Centro-Oeste do Brasil, com a participação de 39 professores universitários, 285 alunos e 7 coordenadores, respondendo a questionários e entrevistas semiestruturadas e postando mensagens no Facebook, relacionadas à cultura digital e ao processo educacional formativo. Os resultados apontam para um contexto de descompasso entre as idas e vindas de professores universitários, alunos e coordenadores, buscando se apropriar das tecnologias de forma a inventar outras formas de ensinar e aprender, em diferentes tempos e espaços, individual e colaborativamente, com abertura para a inovação de forma crítica.

Palavras-chave:cultura digital; tecnologias; processo educativo formativo; abordagem da etnografia virtual. Resumen: Esta investigación tiene el objetivo de analizar redes de relaciones en el contexto de la cultura digital con un enfoque en los vínculos entre tecnologías, coordinadores, profesores universitarios y estudiantes. Se trata de una investigación cualitativa, con enfoque de etnografía virtual, desarrollada en una universidad privada en el Medio Oeste de Brasil, con la participación de 39 profesores universitarios, 285 estudiantes y 7 coordinadores, respondiendo cuestionarios y entrevistas semiestructuradas, y publicando mensajes en Facebook, relacionado con la cultura digital y el proceso de formación educativa. Los resultados apuntan a un contexto de desajuste entre las idas y venidas de profesores universitarios, estudiantes y coordinadores, buscando tecnologías apropiadas para inventar otras formas de enseñanza y aprendizaje, en diferentes tiempos y espacios, de manera individual y colaborativa, con apertura a innovación críticamente.

Palabras clave: cultura digital; tecnologías; proceso educativo formativo; enfoque de etnografía virtual.

\footnotetext{
1 Universidade Católica Dom Bosco (UCDB), Campo Grande, Mato Grosso do Sul, Brasil.
} 


\section{INTRODUÇÃO}

This research analyzed networks of relationships in the context of digital culture: technologies, coordinators, university teachers and students. To understand them, we characterize the subjects; which technologies are part of their life; some conceptions about technologies and digital culture; and some of their uses and implications in the education process.

Therefore, this research is justified in the sense of understanding how the networks of relations happen in the university scope and if they propitiate or not the establishment of a digital culture and some implications in the formative process.

We started by presenting the research methodology. Next, we bring some theoretical points about technologies, digital culture and formative education process. Finally, we present the analyzed data and some final considerations.

\section{METHODOLOGY: SOME TRAILED ROADS}

The research adopts the qualitative approach, which works with the universe of meanings, motives, aspirations, beliefs, values and attitudes (MINAYO, 2012). The phenomena listed by the author represent part of the social reality. We emphasize that the human being is distinguished by the actions and the reflection from a given context lived and shared with other individuals.

We adopted the virtual ethnography approach as it takes the internet into account as part of its field of connection (HINE, 2000). It has been used to search for online social networks established in various media and it analyzes social practices on the Internet and their participants meanings. Therefore, we understand that through it, it is possible to discuss the networks among technologies, coordinators and university teachers and students. Still, Hine (2000) defines as fundamental base of the virtual ethnography the need of the researcher to deepen in the study world for a certain time, understanding that the relations are formed with those who participate in the social processes.

Accordingly, to Hine (2015), applying an ethnographic approach to the Internet requires some specific types of creativity in order to be able to detail the ways in which online activities make sense. Ethnographers are flexible people who develop their methods in response to their contexts, and each study is therefore unique in its approach. The three Es (embedded, embodied and everyday) identify aspects of ethnography that align with specific methodological strategies, which somehow connected online and offline and attempted to reflect on how the Internet makes sense.

This research was developed at a private university in the center-west of Brazil, with the participation of 39 university teachers, 285 students from 34 undergraduate courses and 07 coordinators, answering questionnaires and semi-structured interviews, and posting messages at Facebook, related to the digital culture and the formative educational process.

The questionnaires were available on google drive and were divided into sessions regarding personal information; educational process; professional process and practices; uses of computers, internet and technologies inside and outside the university context. Some questions were closed, and some were open-ended, depending on the topic. It was almost the same questionnaire to all participants, except for the part about the specific educative practices from teachers and coordinators. 
The semi-structured interviews, with closed and open-ended questions, focused the theme about digital culture, concepts, experiences, problems and solutions on dealing with the digital technologies at different contexts, specially at the educational one.

The Facebook was used as a space where the participants could share their experiences, expectations, curiosities and knowledge about technologies and digital culture at the educational contexts, as teaching, learning, researching and formative activities.

It is important to mention that this research was approved by the ethics committee and the anonymity of all participants was maintained with the use of fictitious names.

\section{TECHNOLOGIES, DIGITAL CULTURE AND FORMATIVE EDUCATIONAL PROCESS}

It is possible to affirm that today we live with the most different technologies ("old or new") and they have implied in our lives: in the ways we think, relate to ourselves and to the others, educate, construct and (re) elaborate our practices, our forms of communicating and interacting with the other and with the world.

Living in a society called technologic, we are challenged to learn in a flexible, participatory and interdependent way. In addition to using technologies in an instrumental way, aimed at solving immediate problems and reproducing mechanical practices, we are called upon to appropriate them in an innovative, dialogic, collaborative, reflexive and critical manner, in order to (re)invent and (re) construct meanings that compose our formation and permanent learning, in different contexts and situations.

The appropriation and incorporation of the technologies can not be done, as Pretto and Silveira (2008) suggest, merely as complementary tools, which are the animators of the traditional processes of teaching and learning.

In the words of Barreto (2001, p. 155, our translation), "It is necessary to think about educational informatics, in the sense of educational incorporation of its resources". Furthermore, it is necessary to resize digital technologies and social networks in relation to education as an emancipatory right and practice. Therefore, it is necessary to re-invent and socialize pedagogical practices that encourage adding new meanings to digital technologies and social networks in the school curriculum, in teaching practice, in the lived experiences and in the daily lives of students

In this perspective, the challenges posed by digital technologies are mobilizing and can bring innovations to the pedagogical practice, implying learning at the technological and methodological level, but also at the relational level, with networks of humans producing and sharing knowledge. According to Silva (2020) the teacher needs to teach students through the collaborative construction of knowledge, making them active subjects in the educational process, "[...] proposing more communicative curricular practices, with more and better authorship and collective and network mediations" (p. 88, our translation).

We know that contemporary students are children and young people who were born in the digital generation, it is these students who live in cyberspace learning anywhere and anytime through mobile devices, connection networks, however, teachers need to have access of skills and abilities on the use, to explore it in all its potentialities, and with that, promote interaction and assist in the educational process. We understand technologies as cultural artifacts, the product of cultural needs. Through the development and deployment of artifacts that embody intentions 
and desires, human beings gain interference with their needs. Artifacts become mediators of human relations with the world and enhance cognitive capacities by acting as technical and psychological tools (BANNELL et al, 2016).

From the context of technologies as cultural artifacts, the digital culture can be developed. For Lévy (2010), cyberculture is the set of techniques (material and intellectual), practices, attitudes, modes of thought and values that develop together with the growth of cyberspace. In the context of cyberculture, we begin to experience different existences of languages, cultures, dialogues, being and living, linked to ubiquity and accessibility. It is not a question of using technologies at any cost, but to consciously and deliberately accompany a change in civilization that deeply questions the institutional forms, mindsets and culture of traditional education systems and, above all, the roles of teacher and student (LÉVY, 2010).

Thus, reflecting on digital culture also makes us reflecting on digital education in times of pandemic. According to Moreira and Schlemmer (2020, p. 25):

Indeed, and as we have already mentioned the pandemic, it is generating the obligation, and, simultaneously, the opportunity for teachers and students to emerge in this Digital Education, especially in the scenarios and realities of the synchronous and asynchronous digital teaching and learning environments. But what seems to be happening, at this time of emergency, is the transfer and transposition of physical classroom teaching methodologies and practices to digital online environments. In most cases, web conferencing technologies and digital platforms are used in a purely instrumental perspective, reducing methodologies and practices to masterful teaching and pedagogy, and comments on social networks are multiplying with recurring statements about the how easy it is to be a teacher of "Distance Learning" and eLearning. And if this conception avenges the opportunity, it will have been lost and the image that will be built of this technology (in a broad sense) will be reduced to the idea of an instrument or tool. (Our translation).

The authors contribute to the discussion bringing the conception of "onlife", instead of "online", expanding the reductionist perspective of technology turned exclusively as a tool, to a hyperconnected and interactive perspective.

In reality, more than this reducing vision of technology, it is necessary to change the paradigm, to the Onlife paradigm, term that originated in the Onlife Initiative project, launched by European Commission, which was essentially concerned with understanding what it means to be human in a hyperconnected reality. In The Onlife Manifesto (FLORIDI, 2015), resulting publication of the project, which defends the end of the distinction between offline and online, it was concluded that TD and communication networks do not can be seen as mere tools, instruments, resources, support, but environmental forces that increasingly affect the our self-conception (who we are), our interactions (as socialize), how we teach and how we learn, in short, our conception of reality and our interactions with reality. Since, in each case, TD has meaning in terms of ethical, legal and political terms causing the weakening of distinction between reality and virtuality; the weakening of the distinction between human, machine and nature; reversing a situation from scarcity to abundance of information; and the passage the primacy of properties, individualities and binary relations for the primacy of connectivity, processes and networks. (MOREIRA; SCHLEMMER, 2020, p. 25, our translation).

In order to discuss educational formation, we agree with Imbernón and Freire, because our understanding is also the one that transcends the vision of teaching that intends a mere scientific, pedagogical and didactic updating [creating] spaces of participation, reflection and formation (IMBERNÓN, 2004). We believe in an educational formation through networks of collaboration 
in which no one educates anyone, nor does anyone educate himself: men and women educate themselves in communion, mediated by the world (FREIRE, 1993).

Such collaboration networks are brought as central to the teaching-learning process:

[...] it is no longer in the teacher who transmits information (Escola Tradicional), nor in student-centered learning (Escola Nova) or technology (Escola Tecnicista). The focus is on the network! The actor is the network! Networks of human beings (teachers, students, cultural practitioners) and technical objects co-creating in the city-cyberspace interface. [...] Creating, sharing, remixing, reusing information and knowledge in a network and in a collaborative way are challenges for education in times of cyberculture in the age of mobility. (SANTOS, 2014 , p. 48, our translation)

According to Martín-Barbero (2003), the study of uses compels us to move the space of interest from the means to the place where its meaning is produced: social movements and a special way for those who leave the neighborhood. Therefore, we need to understand digital culture from the needs, desires and uses that universty teachers, coordinators and students make of it.

\section{ANALYZED DATA: RELATIONSHIPS IN DIGITAL CULTURE}

For this article, we considered only the data which had more than half percentage from the respondents. Regarding the profile of teachers, more than $50 \%$ of them are between 31 and 45 years of age, are masters, have already participated in face-to-face and distance continuous training education, have experience in teaching more than 6 years, have a minimum of 21 hours a week dedicated to teaching, and work in a single university.

It is interesting to note that they did not attend specific discipline dealing with the technologies during their higher education, however they believe that if there were such discipline it could have contributed a lot.

Another curious aspect is that they take their laptops to the university to support the pedagogical activities with the students, even though they already have a fixed computer in their classrooms. This may reveal a greater familiarity in using their own technological artifact, with more security and propriety, leaving some kind of discomfort behind using a different one.

Regarding to the use of multimedia programs, editing texts and presentations, downloading and installing programs, creating or updating blogs and websites, posting movies or videos, setting privacy options on social networks, they said they had little or no difficulty, considering themselves as users without great technological difficulties. However, it is worth remembering that all these things happen in the personal context, unlike the professional context, which they still feel with little technological skills.

Even knowing that more than $50 \%$ of the students at the university have a cell phone and that the Internet is free, the place that the univeristy teachers use more technologies articulated to their educational practices is still at the computer laboratory, evidencing the little use of mobile applications around the different spaces of the university.

It seems to us that the educational process still has a marked time and place, contrary to what Kenski (2003) points out regarding the transformation of the educational space into the digital age. According to the author, no matter where the student is, since he/she has access to the knowledge available in the networks, he/she can then continue to learn. This causes 
us, educators, to think about other possible times and spaces for our educational practices, as different ways of producing knowledge.

The university teachers fully agree that coordination/direction encourages the use of the internet in pedagogical and administrative activities, a point in favor of educational practices with technologies.

About the contents available on the internet, the university teachers believe that they contribute to the development of knowledge on a specific subject, to the development of betterquality educational materials, to aid in pedagogical practice and to stimulate student interest. The vast majority change the original resources obtained on the Internet, downloading the content and then modifying it, producing new content. In addition, most check permissions to use resources obtained on the Internet.

Regarding the profile of the students, $53 \%$ of the participating students are in the age group up to 20 years, more than $50 \%$ use the computer and the internet to do projects or works on a certain theme and use the cell phone and the internet to participate in social networks.

It is at home where they use the computer and the internet for the educational activities: to talk to the teacher at the internet, to attend distance courses, to do research for the university, to do homework, to do projects or works on a specific theme, to work in groups and to play.

It is also at home that they use their cell phones and the Internet in their activities: to talk to the teacher at the internet, to participate in distance learning courses, to play games and to participate in social networks.

There is a certain mismatch between teachers and students regarding digital culture. The formers believe that even students having facilities and familiarity with technologies and social networks, they are not yet educated for this, that is, they still lack the responsibility and autonomy not to get lost in the entanglements of the network. On the other hand, students believe that teachers could risk more by innovating pedagogical practices according to the culture of the 21st century. We believe that the two sides seek an educational context with more quality and innovation, not linked to the modism and a technological submission, but to a critical dialogue with pedagogical, methodological and curricular questions.

Regarding the profile of the coordinators, all of them are in the age range from 31 to 45 years. About the main priorities relating to the pedagogical objectives and to the use of computers and internet at the university, the coordinators pointed out: to improve the appropriation of teachers in the use of technologies; to dare new teaching and learning methods through the use of technologies; to increase the speed of internet access; to keep computers always running, and to encourage responsible internet use for students.

More than $60 \%$ of the coordinators fully agree that information and communication technologies are considered relevant at the university. However, they believe that computer, internet, and teaching and learning practices can still be boosted and that there are still some infrastructure limitations.

About what coordinators do with the computer and the internet, it is still a very restricted use of writing documents, reports and communications; manage the agenda, communicate with teachers and students, failing to take advantage of the potential from other types of knowledge production subsidized by technologies.

According to the architecture and engineering coordinator, in his work area, digital culture is already part of everyday life, most of them already work with/in digital culture. Such a statement 
must be considered under the care of not falling into the technicality, accentuating only the technical questions and seconding the personal, social, educational and relational aspects.

We agree with Cazeloto (2009), Lemos (2009) and Lessig (2008) when they affirm that the change should go beyond the so-called technicalism because it involves not only dialectical relations but also artistic and identity manifestations, as well as the principles of collaboration, of horizontality, of decentralization in public-private-social relations.

It is interesting to notice that there is some kind of reflection about what kind of innovation we are talking about when we refer to technologies, that is, the insertion of digital technology is not enough. It is also necessary teacher and student education to get profit of it in a critical way:

I don't know. I have already taught, for example, using WhatsApp. But I don't know if it is innovation or something audacious. What I see is that the student today has many facilities with the technologies and with the social network, but it is very easy for them to distract themselves with things not part of the class. For example, I have gone to the lab many times to use some social network. Then, you give the students some orientation and you trust them, and you get close them and see they are doing other things and not the one proposed for class. So, maybe, student education is missing. The teacher education, but the student education too... (Interview - TEACHER A, 2018, our translation).

On the other hand, it is also pointed the opportunities the digital technologies can bring us, like access to research virtually, build and socialize knowledge and also develop autonomy:

I think that the possibility of research as access to books and articles in virtual libraries are ways of democratizing the access to knowledge. We can use labs and produce works to socialize knowledge. We can use images, music and videos to learn some determined content. The student will not be just a receptor. He/She will be able to develop his/her autonomy to build knowledge. (STUDENT C, 2018).

We do not think of innovation as something completely new, since we agree with Guazzelli (2015), mentinoning Paulo Freire, that innovating is not creating from nothing but having the wisdom to search the old, with the dream of making a quality school for a critical citizenship. Therefore, permanent dialogues and problematizations about how to integrate technologies critically at the educational context are necessary.

Hernández et al. (2000) propose to think about innovation from the multiplicity of views and the complexity that involves the webs of the subjects' experiences:

[...] innovation is not the same for those who promote it, for those who facilitate it, for those who put it into practice or for those who receive its effects. Therefore, the definition of what constitutes an innovation results from the confluence of a plurality of views and opinions that come from those who have some type of relationship with it. (HERNÁNDEZ et al., 2000, p. 19, our translation).

Therefore, we think of technologies in the context of digital culture from a collaborative, dialogical, critical and plural perspective, in order to enable multiple and different views in the processes of teaching and learning with innovation.

\section{SOME CONSIDERATIONS}

The introduction of technologies is already a fact, in different contexts, with greater or lesser difficulties, both in technical terms and in terms of epistemological and pedagogical foundations. 
There is a consensus about their importance, their discussion, their problematization, and their appropriation. Still, we perceive by the answers, how much the university, despite all the incentive, does not enjoy its potentialities and possibilities, sometimes for lack of knowledge, sometimes for lack of adequate structure, or for lack of involvement with the new demands.

We risk saying that this context is permeated by cultures experienced and expressed in the data, providing new (dis)connections and (inter)relations between different readings and emerging meanings in the group of university teachers, students and coordinators. There are advances and setbacks, in coming and going alternated routes, but with other possibilities of educating, individually and collaboratively, in different spaces and times, with the necessity of openness to other educational experiences.

\section{SCIENTIFIC OR SCHOLARLY SIGNIFICANCE OF THE STUDY}

Understanding the phenomenon of digital culture in the educational context, more specifically in a private university situated in the center-west of Brazil, its implications in pedagogical practices and the interrelations of university professors, coordinators and students, enables us to think, reflect and re (elaborate) other ways of teaching and learning, different possibilities of producing knowledge in times and spaces beyond the physical classroom. The more we know about the digital culture that surrounds us, the more we can take advantage of its potentialities by seeking alternatives for educational improvements.

In the context of a pandemic, which we are experiencing, in which educational processes have to be mediated by information and communication technologies in order to replace physical presence, it requires that we, educators and researchers, turn to other possibilities of educating and to educate themselves, valuing the relationships among teachers, students, managers and technologies, with quality, criticality and innovation, never disregarding personal, subjective, contextual aspects. Although they can be different and diverse, they should be seen as enriching more inclusive, participatory and collaborative practices. Therefore, perhaps this text can provide a start for such reflection.

\section{REFERENCES}

BANNELL, R. I.; DUARTE, R.; CARVALHO, C.; PISCHETOLA, M.; MARAFON, G.; CAMPOS, G. H. B. Educação no século XXI: cognição, tecnologias e aprendizagens. Petrópolis: Vozes; Rio de Janeiro: PUC, 2016.

BARRETO, R.G. (Org.). Tecnologias educacionais e educação a distância: avaliando políticas e práticas. Rio de Janeiro: Quartet, 2001.

CAZELOTO, E. Apontamentos sobre a noção de "democratização da internet". In: TRIVINHO, E.; CAZELOTO, E. A cibercultura e seu espelho: campo de conhecimento emergente e nova vivência humana na era da imersão interativa. São Paulo: ABCiber; Instituto Itaú Cultural, 2009.

FLORIDI, L. (Ed.). The onlife manifesto: being human in a hyperconnected era. London: SpringerOpen, 2015. 255 p. Disponível em: https://link.springer.com/content/pdf/10.1007\%2F978-3-319-04093-6.pdf. Acesso em: 10 fev. 2020.

FREIRE, P. Política e educação. São Paulo: Cortez, 1993.

INTERAÇÕES, Campo Grande, MS, v. 22, n. 3, p. 705-714, jul./set. 2021. 
GUAZZELLI, D. C. H. R. Inovações pedagógicas com o uso de tecnologias. In: GOMEZ, M. V. Círculo de Cultura Paulo Freire: arte, mídia e educação. São Paulo: Fundação Memorial da América Latina, 2015.

HERNÁNDEZ, F.; SANCHO, J. M.; CARBONELL, J.; TORT, A.; SIMÓ, N.; SÁNCHEZ-CORTÉS, E. Aprendendo com as inovações na escola. Porto Alegre: Artmed, 2000.

HINE, C. Virtual ethnography. London: SAGE Publications, 2000.

HINE, C. Por uma etnografia para a internet: transformações e novos desafios. [Entrevista concedida a] Christine Hine. MATRIZes, São Paulo, v. 9, n. 2, p. 167-73, jul./dez. 2015.

IMBERNÓN, F. Formação docente e profissional: formar-se para a mudança e a incerteza. São Paulo: Cortez, 2004.

KENSKI, V. Tecnologias e Ensino presencial e a distância. Campinas: Papirus, 2003.

LEMOS, A. A cibercultura como território recombinante. In: TRIVINHO, E.; CAZELOTO, E. A cibercultura e seu espelho: campo de conhecimento emergente e nova vivência humana na era da imersão interativa. São Paulo: ABCiber; Instituto Itaú Cultural, 2009.

LESSIG, L. Remix: making art and commerce thrive in the hybrid economy. New York: The Penguin Press, 2008.

LÉVY, P. Cibercultura. 3 ed. São Paulo: Editora 34, 2010.

MARTíN-BARBERO, J. Dos meios às mediações. Rio de Janeiro: UFRJ, 2003.

MINAYO, M. C. S. Pesquisa social: teoria, método e criatividade. 32. ed. Petrópolis: Vozes, 2012.

MOREIRA, J. A.; SCHLEMMER, E. Por um novo conceito e paradigma de educação digital onlife. Revista UFG, Goiânia, v.20, n. 26, p. 63438, 2020.

PRETTO, N.; SILVEIRA, S. A. Além das redes de colaboração: internet, diversidade cultural e tecnologias do poder. Salvador: EDUFBA, 2008.

SANTOS, E. A cibercultura e a educação em tempos de mobilidade e redes sociais: conversando com os cotidianos. In: FONTOURA, H. A; SILVA, M. (Org.). Práticas pedagógicas, linguagem e mídias: desafios à pós-graduação em Educação em suas múltiplas dimensões. Rio de Janeiro: ANPEd Nacional, 2011.

SANTOS, E. Pesquisa-formação na cibercultura. Santo Tirso: Whitebooks, 2014.

SILVA, R. N. K. O perfil necessário ao professor frente à influência da cibercultura no contexto educacional. ReDoC-Revista Docência e Cibercultura, Rio de Janeiro, v. 4, n. 2, p. 103-18, 2020.

\section{About the authors:}

Maria Cristina Lima Paniago: Doctorate and Master's Degree in Applied Linguistics and Language Studies from the Pontifical Catholic University of São Paulo (PUC-SP). Graduated in Arts from the United Catholic Colleges of Mato Grosso (FUCMAT). Visiting Researcher at the University of Manitoba, Canada. Professor of the Postgraduate Program in Education, Masters and Doctorate at the Dom Bosco Catholic University (UCDB). She is the leader of the Research and Studies Group on Educational Technology and Distance Education (GETED). She is deputy institutional coordinator at the UCDB of the Be_a_DOC Coimbra 
Group. Research Productivity Scholarship 2 CNPq. E-mail: cristina@ucdb.br, Orcid: https://orcid.org/0000-0002-8631-4961

Rosimeire Martins Régis dos Santos: Doctorate in Education from the Dom Bosco Catholic University (UCDB), sandwich period from the University of Manitoba, Canada. Master in Education from UCDB. Post-Graduate Lato Sensu in Advanced Human Resources Management at UCDB. Post-Graduate Lato Sensu in Rural Education from the Federal University of Mato Grosso do Sul (UFMS). Post-Graduation Lato Sensu in Salesianity at UCDB. Graduation in Teacher Education from UCDB; and in Pedagogy at the University Center of Grande Dourados (UNIGRAN). Research professor in Scientific Research activities under the Dean of Research and Graduate Studies and the Institutional Program for Scientific Initiation Scholarships (PIBIC) at UCDB. E-mail: profarosimeireregis@hotmail.com, Orcid: https://orcid.org/0000-0001-5744-4778

Arlinda Cantero Dorsa: Doctorate in Portuguese Language from the Pontifical Catholic University of São Paulo (PUC-SP). Master's Degree in Communication and Letters from Universidade Presbiteriana Mackenzie. Graduated in Letters with French from the United Catholic Colleges of Mato Grosso (FUCMAT). Editor of the International Magazine Interactions. Vice-coordinator and professor of the Post-Graduate Program (Masters and Doctorate) in Local Development and of the Law course at the Dom Bosco Catholic University (UCDB). Leader of the Cultural Heritage, Law and Diversity Research Group (CNPq). Member of the Historical Institute of Mato Grosso do Sul. Researcher of Scientific Initiation, Masters and Doctorate. E-mail: acdorsa@ucdb.br, Orcid: https://orcid.org/0000-0002-1120-0273 